\title{
LOST ROMANTICS AND OTHER PEASANTRIES
}

One grew up and chanted. One grew up And the expressions spelled magnanimity, But the hearts said shoplifting. Not outright Larceny, the kind that befalls foliage

In late autumn, and then later, but quaint Kleptomania before it took root, its foothold, Like an ancient tuber, quintessential tuber, Either the symbol of sustenance or indefatigable Portent of something self-conscious, something Dangerous if only because it was aware of itself, Nothing more threatening than a spud in the earth, Precisely the fact of a spud in the dirt, waiting To be pulled up by a bad back and big hands, Bulbous paws. Normal was always meant to be

Well, normal, but everything was just too quiet, Everything was too quiet on the streets and we knew.

It's hard to speak out when there's no place To hide, no place to sequester oneself if just To get stashed for a moment, just for some respite Even when there's no need, no stolen goods Or loss of memory, nothing more mournful Than when you say po-tah-to and I say... 